\title{
First discovery of a rare polygyne colony in the stingless bee Melipona quadrifasciata (Apidae, Meliponini)*
}

\author{
Denise Araujo Alves ${ }^{1}$, Cristiano MENEZES $^{2}$, Vera Lucia IMPERATRIZ-FonSECA ${ }^{1,2}$, Tom WenSELEers ${ }^{3}$ \\ ${ }^{1}$ Laboratório de Abelhas, Departamento de Ecologia, IB, Universidade de São Paulo, Rua do Matão Trav. 14, 321, \\ 05508-090 São Paulo, São Paulo, Brasil \\ ${ }^{2}$ Laboratório de Abelhas, Departamento de Biologia, FFCLRP, Universidade de São Paulo, Av. Bandeirantes, 3900, \\ 14040-901, Ribeirão Preto, São Paulo, Brasil \\ ${ }^{3}$ Laboratory of Entomology, Zoological Institute, Catholic University of Leuven, Naamsestraat 59, 3000 Leuven, \\ Belgium
}

Received 28 February 2010 - Revised 11 May 2010 - Accepted 23 May 2010

polygyny / relatedness / reproductive skew / stingless bees

Stingless bees are highly eusocial bees, and are characterised by having perennial colonies that are typically headed by one single-mated queen (Peters et al., 1999). The main exception to this pattern is found in Melipona bicolor, which is the only stingless bee species discovered so far to exhibit facultative polygyny, whereby several queens may coexist and share reproduction inside the colony for considerable periods of time (Bego, 1989; Velthuis et al., 2006). Aside from that, there are, for a few stingless bee species, also some anecdotal reports of temporary, transient episodes of polygyny (e.g. in M. scutellaris, Carvalho-Zilse and Kerr, 2004; Plebeia droryana, Silva, 1972; and P. wittmanni, Witter and Wittmann, 1997), which are usually associated with queen replacement events. Here we report on a novel case of occasional polygyny in the stingless bee $M$. quadrifasciata, in which an exceptionally high number (8) of egg-laying queens were found to coexist inside the same colony. In addition, and in contrast to some of the earlier studies demonstrating occasional polygyny in stingless bees, which were purely based on observations, we provide the first genetic data about the reproductive partitioning and relatedness among these different queens.

The polygyne $M$. quadrifasciata colony was first discovered by a beekeeper of stingless bees, Mr. Cleiton Geuster, in Luzerna, Santa Catarina

Corresponding author: D.A. Alves, daalves@ib.usp.br

* Manuscript editor: Marla Spivak state, where he maintained a total of 9 colonies of this species. In July 2009, the colony was found to be headed by a single mother queen, but one month later it underwent a queen supersedure event whereby the old queen died and 8 newly mated queens were adopted. Subsequently, the polygyne colony, containing around 1000 workers, was transferred to the University of São Paulo, Ribeirão Preto for further study. Polygyny was maintained for a total of ca. 4 months, after which the colony adopted a new queen and reverted back to a monogynous state.

To determine how the reproduction was partitioned among the different queens and to find out whether or not they were related (daughters of the previous queen, as opposed to unrelated social parasites), we collected female brood ( $n=168 \mathrm{fe}$ male pupae) as well as wing tips from all eight physogastric queens for further genotyping. In addition, we also genotyped 22 foragers which given their age were most likely the offspring of the replaced mother queen, and we sampled 10 worker pupae from each of the remaining eight colonies kept in the apiary. Subsequently, DNA was extracted using the Chelex method and samples were genotyped at four microsatellite markers, T4-171 (Paxton et al., 1999), Mbi-201 and Mbi-278 (Peters et al., 1998) and Mru-03 (Lopes et al., 2009), using multiplex PCR reactions and a touchdown PCR programme, as described previously (Alves et al., 2009). PCR amplification products were run on a 3130 Avant capillary DNA sequencer and alleles 
Table I. Genotypes of the physogastric queens of the polygyne Melipona quadrifasciata colony and the inferred genotype of their superseded mother and her mate.

\begin{tabular}{lcccc}
\hline \multirow{2}{*}{ Queen } & \multicolumn{4}{c}{ Genotypes at locus } \\
\cline { 2 - 5 } & T4-171 & Mbi-201 & Mbi-278 & Mru-03 \\
\hline SC 9-a & $109 / 109$ & $165 / 168$ & $185 / 188$ & $128 / 128$ \\
SC 9-b & $109 / 109$ & $165 / 168$ & $185 / 188$ & $118 / 128$ \\
SC 9-c & $109 / 109$ & $165 / 168$ & $185 / 188$ & $118 / 128$ \\
SC 9-d & $109 / 109$ & $162 / 168$ & $185 / 188$ & $118 / 128$ \\
SC 9-e & $109 / 109$ & $165 / 168$ & $185 / 188$ & $118 / 128$ \\
SC 9-f & $109 / 109$ & $162 / 168$ & $185 / 188$ & $118 / 128$ \\
SC 9-g & $109 / 109$ & $165 / 168$ & $185 / 188$ & $118 / 128$ \\
SC 9-h & $109 / 109$ & $165 / 168$ & $185 / 188$ & $128 / 128$ \\
Inferred parental genotypes: & $109 / 109 \times 109$ & $162 / 165 \times 168$ & $185 / 185 \times 188$ & $118 / 128 \times 128$ \\
& & \multicolumn{3}{c}{ or $188 / 188 \times 185$} \\
\hline
\end{tabular}

were identified using the supplied GeneMapper software. SPAGeDI was used to calculate the genetic relatedness among the workers ( $r$ ) (Hardy and Vekemans, 2002), following the estimator given in Queller and Goodnight (1989). The genetic relatedness among workers was then used to estimate the effective number of laying queens $\left(N_{e}\right)$ inside the nest, $N_{e}=(3-G) /(4 r-G)$, where $G$ is queen-queen relatedness (Pamilo, 1991), as well as the maternity skew, using the index $S=\left(N_{t}-N_{e}\right) /\left(N_{t}-1\right)$, where $N_{t}$ is the total number of queens inside the colony (8). This skew index ranges between 0 (no skew) and 1 (one queen carries out all reproduction) (Pamilo and Crozier, 1996).

Loci were reasonably polymorphic, with $5,3,2$ and 7 alleles detected and mean expected heterozygosities of $41.08 \%, 62.18 \%, 38.52 \%$ and $77.67 \%$ at loci T4-171, Mbi-201, Mbi-278 and Mru-03, respectively. For 8 out of 9 of the studied colonies, the genotypes of the worker pupae were consistent with the colonies being headed by a single oncemated queen, as is typical for stingless bees (Peters et al., 1999). In addition, the genotypes of the newly established queens in the polygyne colony demonstrate that they were almost certainly full-sisters and therefore daughters of the previous queen (Tab. I). The genotypes of 19 out of 22 of the foragers genotyped from this colony were consistent with them being derived from the superseded queen. A small number of foragers $(3 / 22)$, however, had genotypes that were incompatible with either the genotype of the superseded queen or that of any of the currently established queens, which means they had probably drifted from other hives nearby (cf. Peters et al., 1999; Palmer et al., 2002). The average relatedness among workers in the polygyne colony, calcu- lated from the genotypes of worker pupae, was low, $r=0.30$, consistent with multiple laying queens being present. Indeed, the estimated effective maternity was 5 , which was very high, although slightly lower than the observed absolute number of queens, 8 . The reproductive skew estimated from these figures was $S=0.43$, which was significantly higher than 0 , expected if all queens would have shared reproduction equally.

Our study is the first to demonstrate occasional polygyny in $M$. quadrifasciata, one of the most intensely studied species of stingless bees. The high effective number of laying queens (5) that we found in this rare polygyne colony was remarkable, given that even in $M$. bicolor, the average effective number of laying queens in polygyne colonies is only ca. 1.5 (D.A. Alves, unpubl. data), and that in other stingless bees where occasional polygyny has been found, normally no more than two laying queens coexist at the same time (Silva, 1972; Witter and Wittmann, 1997; Carvalho-Zilse and Kerr, 2004). We suggest that these occasional episodes of polygyny may occur when multiple virgin queens emerge and leave on their mating flights around the same time, thereby exploiting the short window during which newly mated queens may be accepted by the workers (Koedam, 1995; Wenseleers, 2004). In Melipona, this might not be so uncommon given the high levels of queen overproduction that are found in this genus (Kerr, 1969; Santos-Filho, 2006), caused by larval caste self-determination (Bourke and Ratnieks, 1999; Wenseleers and Ratnieks, 2004). If several such queens can simultaneously seize the chance to start reproducing, this will evidently provide them with large individual fitness benefits. Nevertheless, it is 
unlikely to raise the productivity of the colony as a whole, given that in stingless bees, the cell building rate and not queen fecundity limits total colony productivity (Velthuis, 2006). Indeed, it may well be due to this tension between individual and colonylevel interests that polygyny is not more common in stingless bees. Nevertheless, a better understanding of the processes leading to occasional episodes of polygyny might well end up providing novel insights into the evolution of more permanent polygyny in other species of social Hymenoptera.

\section{ACKNOWLEDGEMENTS}

We thank FAPESP (to D.A.A., CM and V.L.I.F.), and the FWO-Flanders (to T.W. and J.B.) for financial support. We are especially thankful to Cleiton Geuster for providing valuable support and allowing us to collect data from his nests, and Raphael Silva to collect part of the field data. We thank anonymous referees for constructive suggestions. Work was carried out under permit numbers 139311 and 09BR003967/DF from the Brazilian Ministry of Environment.

Note scientifique : première découverte d'une rare colonie polygyne chez l'abeille sans aiguillon Melipona quadrifasciata (Apidae, Meliponini).

Eine wissenschaftliche Notiz: Erstbeschreibung einer seltenen polygynen Kolonie der stachellosen Biene Melipona quadrifasciata (Apidae, Meliponini).

\section{REFERENCES}

Alves D.A., Imperatriz-Fonseca V.L., Francoy T.M., Santos Filho P.S., Nogueira Neto P., Billen J., Wenseleers T. (2009) The queen is dead - long live the workers: intraspecific parasitism by workers in the stingless bee Melipona scutellaris, Mol. Ecol. 18, 4102-4111.

Bego L.R. (1989) Behavioral interactions among queens of the polygynic stingless bee, Melipona bicolor bicolor Lepeletier (Hymenoptera, Apidae), Braz. J. Med. Biol. Res. 22, 587-596.

Bourke A.F.G., Ratnieks F.L.W. (1999) Kin conflict over caste determination in social Hymenoptera, Behav. Ecol. Sociobiol. 46, 287-297.

Carvalho-Zilse G., Kerr W. (2004) Substituição natural de rainhas fisogástricas e distância de vôo dos machos em Tiuba (Melipona compressipes fasciculata Smith, 1854) e Uruçu (Melipona scutellaris Latreille, 1811) (Apidae, Meliponini), Acta Amazonica 34, 649-652.
Hardy O.J., Vekemans J. (2002) SPAGeDI: a versatile computer program to analyse spatial genetic structure at the individual or population levels, Mol. Ecol. Notes 2, 618620 .

Kerr W.E. (1969) Some aspects of the evolution of social bees (Apidae), Evolutionary Biology, Vol. 3, AppletonCentury Crofts, New York, pp. 119-175.

Koedam D., Monge I.A., Sommeijer M.J. (1995) Social interactions of gynes and their longevity in queenright colonies of Melipona favosa (Apidae: Meliponinae), Neth. J. Zool. 45, 480-494.

Lopes D.M., Silva F.O.D., Salomao T.M.F., Campos L.A.D.O., Tavares M.G. (2009) Microsatellite loci for the stingless bee Melipona rufiventris (Hymenoptera: Apidae), Mol. Ecol. Res. 9, 923-925.

Palmer K.A., Oldroyd B.P., Quezada-Euan J.J.G., Paxton R.J., May-Itza W.D.J. (2002) Paternity frequency and maternity of males in some stingless bee species, Mol. Ecol. 11,2107-2113.

Pamilo P. (1991) Evolution of colony characteristics in social insects. II. Number of reproductive individuals, Am. Nat. $138,412-433$.

Pamilo P., Crozier R.H. (1996) Reproductive skew simplified, Oikos 75, 533-535.

Paxton R.J., Weissschuh N., Quezada-Euan J.J.G. (1999) Characterization of dinucleotide microsatellite loci for stingless bees, Mol. Ecol. 8, 690-692.

Peters J.M., Queller D.C., Fonseca V.L.I., Strassmann J.E. (1998) Microsatellite loci for stingless bees, Mol. Ecol. 7, 784-787.

Peters J.M., Queller D.C., Imperatriz-Fonseca V.L., Roubik D.W., Strassmann J.E. (1999) Mate number, kin selection and social conflicts in stingless bees and honeybees, Proc. R. Soc. Lond. B, Biol. Sci. 266, 379-384.

Queller D.C., Goodnight K.F. (1989) Estimating relatedness using genetic markers, Evolution 43, 258-275.

Santos Filho P.S., Alves D.A., Eterovic A., ImperatrizFonseca V.L., Kleinert A.M.P. (2006) Numerical investment in sex and caste by stingless bees (Apidae: Meliponini): a comparative analysis, Apidologie 37, 207-221.

Silva D.L.N. (1972) Considerações em torno de um caso de substituiçao de rainha em Plebeia (Plebeia) droryana, in: Cruz-Landim C. (Ed.), Homenagem a W.E. Kerr, Ribeirão Preto, Brazil.

Velthuis H.H.W., Vries H.D., Imperatriz-Fonseca V.L. (2006) The polygyny of Melipona bicolor: scramble competition among queens, Apidologie 37, 222-239.

Wenseleers T., Hart A.G., Ratnieks F.L.W., Quezada-Euan J.J.G. (2004) Queen execution and caste conflict in the stingless bee Melipona beecheii, Ethology 110, 725-736.

Wenseleers T., Ratnieks F.L.W. (2004) Tragedy of the commons in Melipona bees, Proc. R. Soc. Lond. B, Biol. Sci. 271(SUPPL. 5), S310-S312.

Witter S., Wittmann D. (1997) Poliginia temporária em Plebeia wittmanni Moure and Camargo, 1989 (Hymenoptera, Apidae, Meliponinae), Biociências 5, $61-69$. 